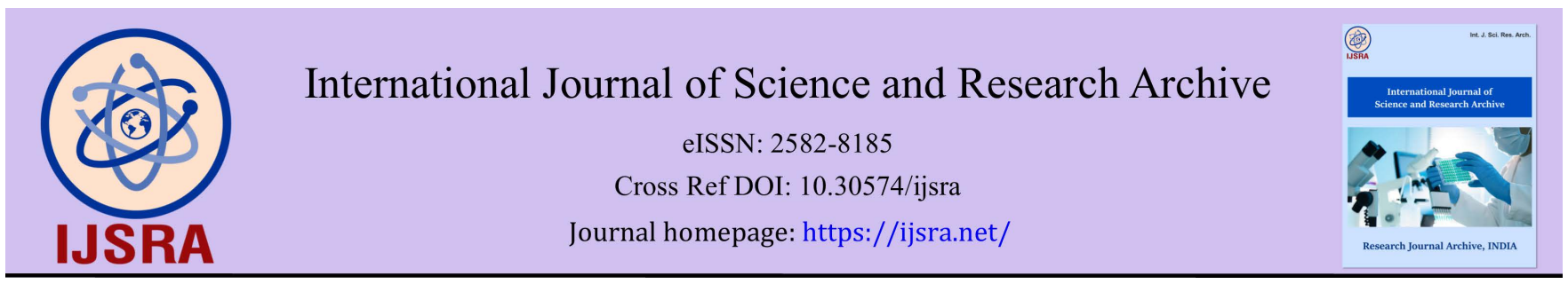

(RESEARCH ARTicle)

\title{
Effect of adoption of sustainable agricultural practices among plantain farmers in Yenagoa agricultural zone of Bayelsa State, Nigeria
}

\author{
Okringbo JI ${ }^{1,}{ }^{*}$, Chukuigwe $\mathrm{O}^{2}$ and Ukohol FY ${ }^{3}$ \\ ${ }^{1}$ Department of Agricultural Economics, Extension and Rural Development Niger Delta University, Wilberforce Island, \\ Bayelsa State, Nigeria. \\ 2 Department of Agricultural Extension Federal University of Technology, Owerri, Imo State, Nigeria. \\ ${ }^{3}$ Institute of Food Security, Federal University of Agriculture, Makurdi, Benue State, Nigeria.
}

International Journal of Science and Research Archive, 2022, 05(01), 114-122

Publication history: Received on 12 January 2022; revised on 18 February 2022; accepted on 20 February 2022

Article DOI: https://doi.org/10.30574/ijsra.2022.5.1.0047

\begin{abstract}
The study analyzed adoption of sustainable agricultural practices among plantain farmers in Yenagoa agricultural zone of Bayelsa State, Nigeria. Purposive and multi-stage random sampling techniques were used to select 100 plantain farmers from ten communities in the study area. Data were collected using structured questionnaire and were analyzed using descriptive and inferential statistics such as (ANOVA) and multiple regression analysis. The findings showed that plantain farmers had a mean age of 39 years, $54.0 \%$ of plantain farmers were females while $46.0 \%$ were females. The result shows that planting time (82.0\%), spacing (79.0\%), pruning (65.0\%) and new varieties $(53.0 \%)$ were the various sustainable agricultural practices provided by extension in the study area. The study further shows that sucker multiplication $(\bar{x}=2.76)$, post-harvest $(\bar{x}=2.60)$ and types of suckers $(\bar{x}=2.28)$ were the sustainable agricultural practices adopted by plantain farmers. Plantain farmers were aware of the following sustainable agricultural practices provided by extension: spacing (100\%), pruning (99\%), planting time (97\%), mulching (77.0\%) and staking (61.0\%). The study also shows that extension was effective in result demonstration $(\bar{x}=3.32)$, agricultural extension visit $(\bar{x}=$ $3.05)$, number of trainings $(\bar{x}=2.99)$, method demonstration $(\bar{x}=2.81)$, research extension linkage $(\bar{x}=2.77)$ and number of meetings scheduled that held $(\bar{x}=2.61)$. The ANOVA result showed that there was significant difference in the effectiveness of extension in sustainable agricultural practices dissemination among plantain farmers in the study area at $5 \%$ level of significance. The multiple regression analysis revealed that age (3.626***) and household size $\left(4.165^{* * *}\right)$ influenced the adoption of sustainable agricultural practices at $1 \%$ level of significance while marital status $\left(2.578^{* *}\right)$, income $\left(2.519^{* *}\right)$ and farm size $\left(2.641^{* *}\right)$ influenced the adoption of sustainable agricultural practices at $5 \%$ level of significance. The study concluded that there was high level of adoption of sustainable agricultural practices by plantain farmers in the study area. Hence, it recommends that extension should vigorously promote the adoption of sustainable agricultural practices for increased plantain production.
\end{abstract}

Keywords: Adoption; Sustainable; Agriculture; Plantain and practice

\section{Introduction}

Nigerian is known for its vast oil and gas resource, however, agriculture had always been the main stay of Nigeria's economy, and accounted for most of its gross domestic product, until recent years (Hamadina and Hamadina, 2015). They further submitted that agriculture is mostly practiced in Nigeria (Bayelsa State inclusive) at subsistence level with little or no mechanization and the farm size is usually less than one hectare. The adoption of sustainable agricultural

\footnotetext{
${ }^{*}$ Corresponding author: Okringbo JI

Department of Agricultural Economics, Extension and Rural Development Niger Delta University, Wilberforce Island, Bayelsa State, Nigeria.
}

Copyright $(2022$ Author(s) retain the copyright of this article. This article is published under the terms of the Creative Commons Attribution Liscense 4.0. 
practices has the potential to improve agricultural sustainability through reduction in agricultural input and less waste generation from the resource (Mwalupso, Korotoumou, Eshetie, Alavo and Tiian, 2019).

Agricultural policies instigated in Nigeria in the last decade, such as the E-wallet programme and Fadama, have brought increased production and improvement in the livelihood and standard of living of the rural population specially in Bayelsa State, thereby stimulating great potential for adoption of sustainable agricultural practices (Apata and Saliu, 2016).

Sustainable agricultural practice is precarious to food security, rural income and employment generation, and economic growth in any given agro-economy. Adoption of various sustainable agricultural practices in reducing poverty in Bayelsa has received huge attention, it remains under-researched (Agbarevo and Okringbo, 2020).

It is very obvious that the yield per hectare in plantain production took a down-ward trend due to low level of adoption of sustainable agricultural practices developed by research for almost a decade (Food and Agricultural Organization, 2011 cited in Kainga, 2013). Effect of adoption of sustainable agricultural practices among plantain farmers in Yenagoa agricultural zone of Bayelsa State, Nigeria are about this is yet to be ascertained. There is no empirical evidence to indicate that a study of the nature has been conducted. It was against this backdrop that this paper seeks to examine the effect of adoption of sustainable agricultural practices among plantain farmers in Yenagoa agricultural zone of Bayelsa State, Nigeria, to fill the gap in knowledge.

\section{Objectives}

This study specifically aimed to:

- Describe the economic characteristics of the respondents in the study area.

- Ascertain sustainable agricultural practices provided by extension.

- Ascertain the level of awareness of plantain farmers on sustainable agricultural mine.

- Examine the effectiveness of extension in sustainable agricultural practice dissemination among plantain farmers.

\subsection{Hypotheses}

\subsection{1. $\mathrm{HO}_{1}$}

There is no significant difference in the effectiveness of extension in sustainable agricultural practices dissemination among plantain farmers in the study area.

\subsection{2. $\mathrm{HO}_{2}$}

Socio-economic characteristics of plantain farmers do not significantly influence their level of adoption of sustainable agricultural practices in study area.

\section{Material and methods}

The study was conducted in Yenagoa Local Government Area of Bayelsa State. The study area lies along latitudes between 40 48' 00" North and 5० 24' 10"East; and longitudes between 6 12' 00"'E and 6 39' 30"E. Yenagoa Local Government area share boundary with Rivers State on the North and East, Delta State on the North West and West, Ogbia LGA on the South East and Southern Ijaw on the South west. Yenagoa Local Government Area had a population of 352, 285 by 1996 estimate (National Bureau of Statistics, 2006). Purposive sampling technique was used to selection of Yenagoa Agricultural Zone, which is the host to Agricultural Development Programmes (ADP). Stratified sampling was used in the selection of the sample size of 100. In the first stage, two extension blocks were randomly selected from the Zone, while in the second stage, 2sub-circle were selected from each block, giving a total of 5 sub-circles. In the third stage, ten farmers were randomly selected from each sub-circle, giving a sample size of one hundred farmers. Data collected through structured questionnaire were analyzed with descriptive statistic, such as mean, while ANOVA and multiple regression was used to test the hypotheses. The questionnaire was a 3-point rating scale of Always adopted, Adopted and not adopted to which numerical values 3, 2 and 1 were assigned respectively. The scores up 6, and gives a mean of 2.0 when divided by 3 . Hence, the cut-off point of 2.0 as the upper limit was used to determine the adoption categories. 


\subsection{Model specification}

$$
\mathrm{Yi}=\mathrm{bo}+\mathrm{b} 1 \mathrm{X} 1+\mathrm{b} 2 \mathrm{X} 2+\mathrm{b} 3 \mathrm{X} 3+\mathrm{b} 4 \mathrm{X} 4+\mathrm{b} 5 \mathrm{X} 5+\mathrm{ei}
$$

Where;

$\mathrm{Y}=$ level of Adoption (measured on a 4-point rating scale)

$\mathrm{X}_{1}=$ Age (measured in years)

$\mathrm{X}_{2}=\operatorname{Sex}($ male $=1$, female $=0)$

$\mathrm{X}_{3}=$ Household size (number of persons eating in the same pot)

$\mathrm{X}_{4}=$ Income (Naira)

$\mathrm{X}_{5}=$ Marital Status $(1=$ married, 0 otherwise $)$

$\mathrm{X}_{6}=$ Farm size $(\mathrm{Ha})$

$\mathrm{e}_{\mathrm{i}}=$ error term

ANOVA as used as Okringbo et al. (2019) is given by the formula:

$$
\mathrm{F}-\text { statistics }=\frac{\text { Between groups mean square }(\text { BGMS) }}{\text { Within groups mean square (WGMS }}
$$

\section{Results and discussion}

The result in Table 1 showed that $42.0 \%$ of plantain farmers were within the age bracket of $34-41$ years old while $29.0 \%$ of the farmers were within the age bracket of 26-33 years. The mean age of the plantain farmers was 39 years old. This implies that most of the plantain farmers in the study area were still in their productive stage in life and would be energetic enough to participate actively in farming activities. More so, it can be inferred that this group of young and energetic farmers would be willing to adopt sustainable agricultural practices that will lead to increased yield. This finding is in conformity with that of Ominikari (2021) who reported a mean age of 39.8 years among sampled rural farmers in Bayelsa State. This finding also agrees with those of Kalu, Nwachukwu and Apu (2021) who reported a mean age of 39.8 years among sampled farmers in Ebonyi State. The result further showed that $66.0 \%$ of the plantain farmers were married while 33.3\% were single. This implies that married individuals dominated among the sampled farmers in the study area. Marital status is an important predisposing factor to enhance income and improve food production. This finding is in tandem with that of Ayoko (2019) which reported that the majority (66.11\%) of sampled rice farmers in Ebonyi State were married. Majority $60.0 \%$ of the plantain farmers had a household size of between 4 and 6 persons per household while $40.0 \%$ of them had a household size of between 7 and 9 persons. The mean household size of the plantain farmers was 6 persons per household. This implies that the plantain farmers in the study area had relatively large household sizes. This implies that there would be added responsibilities of providing for these large families which could be aided by the adoption of sustainable agricultural practices for enhanced agricultural production. Similarly, married farmers would likely have access to production variables such as land and labour which would reduce the cost of hired labour and enhance their agricultural production. This finding is similar to that of Ajunwa (2019) who reported a mean house hold size of 6 persons among sampled farmers in Imo State. The result still revealed that $71.0 \%$ of farmers in the study area had farming experience of between 1-10 years.

Table 2 shows the frequency distribution according to the various sustainable agricultural practices provided by extension in the study area. The result shows that planting time (82.0\%), spacing (79.0\%), type of sucker (75.0\%), mulching (72.0\%), staking (68.0\%), pruning (65.0\%), conventional agricultural practice (64.0\%) and sucker multiplication (61.0\%) were the various sustainable agricultural practices provided by extension in the study area. This implies that sustainable practices such as planting time, spacing, type of sucker, mulching, staking, pruning, conventional agricultural practice, sucker multiplication and new varieties were the various sustainable agricultural practices provided by extension in the study area.

Table 3 shows the mean scores distribution according to the adoption level of sustainable agricultural practices among plantain farmers in Yenagoa Agricultural Zone of Bayelsa State. The result shows that spacing $(\bar{x}=3.00)$ planting time $(\bar{x}=2.91)$, mulching $(\bar{x}=2.78)$, sucker multiplication $(\bar{x}=2.76)$, pruning $(\bar{x}=2.70)$, post-harvest $(\bar{x}=2.60)$ and types of suckers $(\bar{x}=2.28)$ were the sustainable agricultural practices adopted by plantain farmers in the study area. These mean ratings were above the bench mark mean score of 2.05. This might be attributed to the fact that the plantain farmers perceived these agricultural practices to be relevant to increased crop yield. This is in contrary to the findings of Mgbada, Ohajianya and Nzeh (2016) who reported low level of use of sustainable agricultural practices among sampled cassava farmers in Ebonyi State. 
Table 1 Distribution of plantain farmers by their socio-economic characteristics

\begin{tabular}{|c|c|c|c|}
\hline Variables & Frequency $(n=100)$ & Percentage (\%) & Mean \\
\hline \multicolumn{4}{|l|}{ Age (years) } \\
\hline $18-25$ & 2 & 2.0 & \\
\hline $26-33$ & 20 & 29.0 & \\
\hline $34-41$ & 42 & 42.0 & \\
\hline 42 and above & 36 & 27.0 & 39 years \\
\hline \multicolumn{4}{|l|}{ Sex } \\
\hline Male & 46 & 46.0 & \\
\hline Female & 54 & 54.0 & \\
\hline \multicolumn{4}{|l|}{ Marital status } \\
\hline Single & 33 & 33.0 & \\
\hline Married & 66 & 66.0 & \\
\hline Divorced & 1 & 1.0 & \\
\hline \multicolumn{4}{|l|}{ Household size } \\
\hline $1-3$ & - & - & \\
\hline $4-6$ & 60 & 60.0 & \\
\hline $7-9$ & 40 & 40.0 & 6 persons \\
\hline \multicolumn{4}{|c|}{ Educational qualification } \\
\hline No formal education & 29 & 29.0 & \\
\hline Primary education & 68 & 68.0 & \\
\hline Secondary education & 3 & 3.0 & \\
\hline Tertiary education & - & - & \\
\hline \multicolumn{4}{|c|}{ Farming experience (years) } \\
\hline $1-10$ & 71 & 71.0 & \\
\hline $11-20$ & 16 & 16.0 & \\
\hline 21 and above & 13 & 13.0 & 10 years \\
\hline \multicolumn{4}{|l|}{ Farm size (hectares) } \\
\hline $0.1-0.5$ & 33 & 33.0 & \\
\hline $0.6-1.0$ & 34 & 34.0 & \\
\hline $1.1-1.5$ & 33 & 33.0 & 0.9 hectare \\
\hline \multicolumn{4}{|c|}{ Estimated monthly income ( $\mathrm{N}$ ) } \\
\hline $18,000-30,000$ & 30 & 34.0 & \\
\hline $31,000-43,000$ & 64 & 64.0 & \\
\hline $44,000-57,000$ & 6 & 6.0 & \\
\hline 58,000 and above & - & - & $\$ 33,880.00$ \\
\hline
\end{tabular}


Table 2 Distribution according to the various sustainable agricultural practices provided by extension in the study area

\begin{tabular}{|l|c|c|}
\hline Sustainable agricultural practices & Frequency & Percentage \\
\hline New varieties & 77 & 77.0 \\
\hline Planting time & 82 & 82.0 \\
\hline Spacing & 79 & 79.0 \\
\hline Pruning & 65 & 65.0 \\
\hline Mulching & 72 & 72.0 \\
\hline Sucker multiplication & 61 & 61.0 \\
\hline Staking & 68 & 68.0 \\
\hline Conventional agricultural practice & 64 & 64.0 \\
\hline Type of sucker & 75 & 75.0 \\
\hline \multicolumn{2}{|c|}{ Source: Field survey, 2021} & \\
\hline
\end{tabular}

Source: Field survey, 2021

Table 3 Distribution according to the adoption level of sustainable agricultural practices among plantain farmers

\begin{tabular}{|c|c|c|c|c|c|c|}
\hline Sustainable agricultural practices & $\begin{array}{c}\text { Always adopted } \\
3 \\
\end{array}$ & $\begin{array}{c}\text { Adopted } \\
2 \\
\end{array}$ & $\begin{array}{c}\text { Not adopted } \\
1\end{array}$ & $\begin{array}{l}\text { Score } \\
\sum F^{\bar{X}}\end{array}$ & $\begin{array}{l}\text { Mean } \\
\bar{x}\end{array}$ & Remarks \\
\hline New varieties & $0(0)$ & $100(200)$ & $0(0)$ & 200 & 2.00 & Not adopted \\
\hline Planting time & $94(282)$ & $3(6)^{\prime}$ & $3(3)$ & 291 & 2.91 & Adopted \\
\hline Types of suckers & $29(87)$ & $70(140)$ & $1(1)$ & 228 & 2.28 & Adopted \\
\hline Hot water treatment & $1(1)$ & $2(4)$ & $97(97)$ & 102 & 1.02 & Not adopted \\
\hline Spacing & $100(300)$ & $0(0)$ & $0(0)$ & 300 & 3.00 & Adopted \\
\hline Pruning & $70(210)$ & $30(60)$ & $0(0)$ & 270 & 2.70 & Adopted \\
\hline Mulching & $79(237)$ & $20(40)$ & $1(1)$ & 278 & 2.78 & Adopted \\
\hline Fertilizer & $27(81)$ & $4(8)$ & $69(69)$ & 158 & 1.58 & Not adopted \\
\hline Post-harvest & $69(207)$ & $22(44)$ & $9(9)$ & 260 & 2.60 & Adopted \\
\hline Sucker multiplication & $76(228)$ & $24(48)$ & $0(0)$ & 276 & 2.76 & Adopted \\
\hline Debudding & $26(78)$ & $25(50)$ & $49(49)$ & 177 & 1.77 & Not adopted \\
\hline Herbicide & $26(78)$ & $5(10)$ & $69(69)$ & 157 & 1.57 & Not adopted \\
\hline Staking & $2(6)$ & $68(136)$ & $30(30)$ & 172 & 1.72 & Not adopted \\
\hline Grand mean score & & & & & 2.21 & Adopted \\
\hline
\end{tabular}

Source: Field survey, 2021; Decision: $\geq 2.05=$ adopted; $<2.05=$ not adopted

Table 4 shows the frequency distribution according to the level of awareness of plantain farmers on sustainable agricultural practices in the study area. The result shows that farmers were aware of the following sustainable agricultural practices provided by extension: spacing (100\%), type of sucker (99.0\%), pruning (99.0\%), planting time (97.0\%), non-renewable resources (79.0\%), mulching (77.0\%), staking (61.0\%), sucker multiplication (53.0\%), new varieties (52.0\%) and conventional agricultural practice (50.0\%). This implies that sustainable practices such as spacing, type of sucker, pruning, planting time, non-renewable resources, mulching, staking, sucker multiplication, new varieties and conventional agricultural practice were provided by extension in the study area. Awareness of sustainable agricultural practices is significant in predisposing farmers to adopting them for their agricultural activities. This finding is in agreement with those of Ikuerowo and Tehinloju (2021) who reported that arable crop farmers in Ondo State were of bio-organic technologies such as crop rotation (100\%), mixed cropping (100\%) and mulching (79.2\%). 
Table 4 Distribution according to the level of awareness of plantain farmers on sustainable agricultural practices in the study area

\begin{tabular}{|l|c|c|}
\hline Sustainable agricultural practices provided by extension & Aware & Not aware \\
\hline New varieties & $52(52.0)$ & $48(48.0)$ \\
\hline Planting time & $97(97.0)$ & $3(3.0)$ \\
\hline Type of sucker & $99(99.0)$ & $1(1.0)$ \\
\hline Spacing & $100(100.0)$ & $0(0.0)$ \\
\hline Pruning & $99(99.0)$ & $1(1.0)$ \\
\hline Mulching & $77(77.0)$ & $23(23.0)$ \\
\hline Sucker multiplication & $53(53.0)$ & $47(47.0)$ \\
\hline Staking & $61(61.0)$ & $39(39.0)$ \\
\hline Integrated pest management & $35(35.0)$ & $65(65.0)$ \\
\hline Conservation tillage practices to control erosion & $6(6.0)$ & $94(94.0)$ \\
\hline Conventional agricultural practice & $50(50.0)$ & $50(50.0)$ \\
\hline Non-renewable resources & $79(79.0)$ & $21(21.0)$ \\
\hline
\end{tabular}

Source: Field survey, 2021

Table 5 Effectiveness of extension in sustainable agricultural practice dissemination among plantain farmers

\begin{tabular}{|c|c|c|c|c|c|c|c|}
\hline Effectiveness indicators & $\begin{array}{l}\text { Fortnightly } \\
4\end{array}$ & $\begin{array}{l}\text { Quarterly } \\
3\end{array}$ & $\begin{array}{l}\text { Monthly } \\
2\end{array}$ & $\begin{array}{l}\text { Annually } \\
1\end{array}$ & $\begin{array}{l}\text { Score } \\
\sum \boldsymbol{F} \bar{x}\end{array}$ & $\begin{array}{l}\text { Mean } \\
\bar{x}\end{array}$ & Remarks \\
\hline Agricultural extension visit & $45(180)$ & $30(90)$ & $10(20)$ & $15(15)$ & 305 & 3.05 & Effective \\
\hline Fields meeting & $16(64)$ & $21(63)$ & $23(46)$ & $40(40)$ & 213 & 2.13 & $\begin{array}{l}\text { Not } \\
\text { effective }\end{array}$ \\
\hline $\begin{array}{l}\text { Number of meetings } \\
\text { scheduled that held }\end{array}$ & $31(124)$ & $24(72)$ & $20(40)$ & $25(25)$ & 261 & 2.61 & Effective \\
\hline Method demonstration & $43(172)$ & $17(51)$ & $18(36)$ & $22(22)$ & 281 & 2.81 & Effective \\
\hline Result demonstration & $55(220)$ & $28(84)$ & $11(22)$ & $6(6)$ & 332 & 3.32 & Effective \\
\hline Number of trainings & $47(188)$ & $25(75)$ & $8(16)$ & $20(20)$ & 299 & 2.99 & Effective \\
\hline Field workshop & $16(64)$ & $18(54)$ & $20(40)$ & $46(46)$ & 204 & 2.04 & $\begin{array}{l}\text { Not } \\
\text { effective }\end{array}$ \\
\hline $\begin{array}{l}\text { Research } \quad \text { extension } \\
\text { linkage }\end{array}$ & $29(116)$ & $34(102)$ & $22(44)$ & $15(15)$ & 277 & 2.77 & Effective \\
\hline Grand mean score & & & & & & 2.72 & Effective \\
\hline
\end{tabular}

Table 5 shows the mean scores distribution according to the effectiveness of extension in sustainable agricultural practice dissemination among plantain farmers. The result shows that extension was effective in sustainable agricultural practice dissemination through the following ways: result demonstration $(\bar{x}=3.32)$, agricultural extension $\operatorname{visit}(\bar{x}=3.05)$, number of trainings $(\bar{x}=2.99)$, method demonstration $(\bar{x}=2.81)$, research extension linkage $(\bar{x}=2.77)$ and number of meetings scheduled that held $(\bar{x}=2.61)$. These mean ratings were above the bench mark mean score of 2.55. This implies that result demonstration, agricultural extension visit, number of trainings, method demonstration, research extension linkage and number of meetings scheduled that held were the methods employed by extension in 
sustainable agricultural practice dissemination among plantain farmers in the study area. This finding is similar to those of Agbarevo and Okringbo (2020); Agbarevo and Nwogu (2016) who reported that extension agents in Abia State were very effective in the organization of research-extension-farmer input linkage.

Table 6 Analysis of variance results showing difference in the effectiveness of extension in sustainable agricultural practices dissemination among plantain farmers in the study area

\begin{tabular}{|l|l|c|c|c|c|c|}
\hline Variable & & Sum of Squares & Df & Mean Square & F-cal & F-tab \\
\hline \multirow{3}{*}{ Effectiveness } & Between Groups & 105.134 & 9 & 11.682 & 689.402 & 3.04 \\
\cline { 2 - 7 } & Within Groups & 1.525 & 90 & 0.017 & & \\
\cline { 2 - 7 } & Total Source: Field survey data, 2021; Ho: rejected at 5\% level & & \\
\hline \multicolumn{7}{|c}{} \\
\cline { 2 - 7 }
\end{tabular}

The result of the Analysis of Variance (ANOVA) f-test used to test for significant difference in the effectiveness of extension in sustainable agricultural practices dissemination among plantain farmers is presented in Table 6. The result in Table 6 shows that the calculated Anova f-value of 689.402 was significantly higher than the tabulated ANOVA f-value of 3.04 at $P \leq 0.05$, suggesting that there was significant difference in the effectiveness of extension in sustainable agricultural practices dissemination among plantain farmers in the study area. This further implies that the effectiveness of extension in sustainable agricultural practices dissemination among plantain farmers differed significantly across sampled communities in the study area. This might be attributed to factors such as the effectiveness of extension personnel and socio-economic attributes of plantain farmers that may affect the dissemination of sustainable agricultural practices in the study area.

Given that the computed ANOVA f-value of 689.402 is less than the critical ANOVA f-value of 3.04 at $5 \%$ level of significance, the study therefore concludes that there is significant difference in the effectiveness of extension in sustainable agricultural practices dissemination among plantain farmers in the study area.

Table 7 Ordinary Least Square (OLS) multiple regression result of the influence of socio-economic characteristics of plantain farmers on their level of adoption of sustainable agricultural practices in the study area

\begin{tabular}{|l|c|c|c|c|}
\hline Variables & +Linear & Exponential & Semi-log & Cobb douglas \\
\hline Constant & $16.821(5.067)^{* * *}$ & $2.438(19.345)^{* * *}$ & $1.352(4.213)^{* * *}$ & $2.170(6.342)^{* * *}$ \\
\hline Age & $1.566(3.626)^{* * *}$ & $0.063(3.715)^{* * *}$ & $1.538(3.474)^{* * *}$ & $0.062(3.463)^{* * *}$ \\
\hline Sex & $0.284(1.639)$ & $0.011(1.579)$ & $4.399(1.649)$ & $0.173(1.632)$ \\
\hline Marital status & $-0.213(2.578)^{* *}$ & $-0.011(-0.669)$ & $0.024(1.261)$ & $-0.002(0.134)$ \\
\hline Income & $4.295 \mathrm{E}-5(2.519)^{* *}$ & $1.817 \mathrm{E}-6(2.204)^{* *}$ & $0.861(1.883)^{*}$ & $0.038(1.836)^{*}$ \\
\hline Household size & $0.141(4.165)^{* * *}$ & $0.005(3.893)^{* * *}$ & $0.677(2.620)^{* *}$ & $0.026(2.459)^{* *}$ \\
\hline Farm size & $0.183(2.641)^{* *}$ & $0.007(2.195)^{* *}$ & $1.124(3.160)^{* * *}$ & $0.044(3.048)^{* * *}$ \\
\hline R-square & 0.885 & 0.874 & 0.868 & 0.856 \\
\hline Adjusted R & 0.642 & 0.632 & 0.625 & 0.614 \\
\hline F-statistic & $8.311^{* * *}$ & $8.067^{* * *}$ & $7.728^{* * *}$ & $7.246^{* * *}$ \\
\hline
\end{tabular}

Source: Field survey data, 2021; NB: ***,** and * represents $1 \%, 5 \%$, and $10 \%$ significance levels respectively. Figures in brackets are $t$-values and + means lead equation.

The result of the ordinary least square multiple regression analysis used to test the hypothesis that socio-economic characteristics of plantain farmers do not significantly influence their level of adoption of sustainable agricultural practices is presented in Table 7. The result shows that the linear model was selected as the lead model based on the magnitude of the coefficient of multiple determinations $\left(\mathrm{R}^{2}\right)$, the signs of the regression coefficients as they conform to a priori expectation and the number of significant variables. The model shows that the explanatory variables included in the model explained about $88.5 \%$ of the observed variation in respondents' livelihoods indicating goodness of fit of the regression model. Age, marital status, household size, income and farm size were the significant variables that 
influenced adoption of sustainable agricultural practices among plantain farmers in the study area. The coefficient of age $\left(3.626^{* * *}\right)$ was positively related to the adoption of sustainable agricultural practices at $1 \%$ significance level, an indication that a direct relationship exists between the age of farmers and their adoption of sustainable agricultural practices in the study area. This finding is in agreement with Mgbada et al. (2016) who reported that age had significant relationship with the use of sustainable agricultural practices among cassava farmers in Southeast Nigeria. The coefficient of marital status $\left(2.578^{* *}\right)$ was positively related to the adoption of sustainable agricultural practices at $5 \%$ significance level, implying that a direct relationship exists between the marital status of farmers and their adoption of sustainable agricultural practices in the study area. The coefficient of income (2.519**) was positively related to the adoption of sustainable agricultural practices at 5\% significance level, an indication that a direct relationship exists between the income of farmers and their adoption of sustainable agricultural practices in the study area. The regression analysis shows that the computed F-statistic value of 8.311 was significantly higher than the tabulated F-value of 2.56 at $1 \%$ level of significance and 1.96 at 5\% level of significance, therefore the null hypothesis that "socio-economic characteristics of plantain farmers do not significantly influence their level of adoption of sustainable agricultural practices" was rejected and the alternate accepted. The study concluded that adoption of sustainable agricultural practices was dependent on socio-economic characteristics of plantain farmers such as age, marital status, household size, and income and farm size.

\section{Conclusion}

The study concluded that farmers were aware of most sustainable agricultural practices such as spacing, type of sucker, pruning, planting time, non-renewable resources, mulching and staking provided by extension. There was also high level of adoption of these sustainable agricultural practices by plantain and extension was effective in result demonstration, agricultural extension visit, number of trainings, method demonstration, research extension linkage and number of meetings scheduled that held.

\section{Recommendations}

Based on the findings, the following recommendations were made:

- There is the need to vigorously promote the adoption of sustainable agricultural practices provided by extension since there was high adoption level among plantain farmers in the study area.

- This can be achieved through intensifying efforts in the area of awareness creation of such practices.

- There is need for the Agricultural Development Programme (ADP) and other extension agencies to encourage farmers on the continuous adoption of sustainable agricultural practices by sensitizing them on the inherent benefits associated with the use of more internal inputs in food production.

- Attention of extension agencies should be directed towards field meetings and field workshops, which were discovered to be the weak links in the activities of sustainable agricultural practice dissemination. In the study area.

\section{Compliance with ethical standards}

\section{Acknowledgments}

The authors wish to thank and acknowledge academic staff and my graduate candidate for assisting in soliciting information from plantain farmers and Agricultural Development Programme (ADP) staff. Their immense support facilitated the completion of this research study.

\section{Disclosure of conflict of interest}

There was no conflict of interest.

\section{References}

[1] Agbarevo MNB, Okringbo JI. Effect of Technologies of National Root Crops Research Institute, Umudike on poverty reduction among Farmers in Umuahia Agricultural Zone, Abia State. Journal of Community \& Communication Research. 2020; 5(2): 83-90. 
[2] Apata, MO, Saliu O. Impact Assessment of Fadama Project on Agricultural Development in Kwara State, Nigeria. Am J. Exp. Agric. 2016; 10: 1-7?

[3] Ajunwa IS, Assessment of Effectiveness of Local Government councils in Agricultural Extension service delivery in Imo State, Nigeria. A thesis submitted to the department of Rural Sociology and Extension, Michael Okpara University of Agriculture, Umudike, 2019; 50-70.

[4] Ani N. Analysis of sustainability of improved yam production practices among rural farmers in Ebonyi State, Nigeria. M.Sc. Thesis submitted to the Department of Agricultural Extension and Rural Development, Michael Okpara University of Agriculture, Umudike, Abia State, Nigeria. 2019; 70-120.

[5] Ayoko E. Effect of adoption of West African Agricultural Productivity Programme (WAAPP) on Rice Farmers' Production in Ebonyi State Nigeria. M.Sc. Thesis submitted to the Department of Agricultural Extension and Rural Development, Michael Okpara University of Agriculture, Umudike, Abia State, Nigeria. 2019; 60-110.

[6] Chidiebere-Mark N, Ohajianya D, Obasi P, Onyeagocha S. Profitability of rice production in different production systems in Ebonyi State, Nigeria. Open Agriculture. 2019; 4: 237-246.

[7] Ekweanya NM. Analysis of Effectiveness of Transfer and Utilization of Odourless Cassava Fufu Technology among Rural Women in South-East Nigeria. Ph.D. Dissertation submitted to the Department of Agricultural Extension and Rural Development, Michael Okpara University of Agriculture, Umudike, Abia State, Nigeria. 2018; 140-151.

[8] Hamadina MK, Hamadina EI. Smallholder Farmers and Sustainability Issues: the case of Fadama 111 Sub-Projects in Bayelsa State of Nigeria. Journal of Multidisciplinary Science and Technology (JMEST). 2015; 2(4): 854-859.

[9] Ikuerowo, JO, Tehinloju OA. Factors Influencing Arable Crop Farmers' Willingness to Adopt Bio-Organic Technology in Ondo State, Nigeria. Journal of Agricultural Extension. 2021; 25(1): 21-30.

[10] Kalu U, Nwachukwu I, Apu U. Farmers use of improved animal health management technologies in small ruminant production in South East, Nigeria. Journal of Community \& Communication Research. 2021; 6(1): 5360 .

[11] Kainga PE. Budgetary analysis of banana (Musa sapientum L.) and Plantain (Musa paradisiaca L.) production. Journal of Agricultural and Crop Research. 2013; 1(4): 55-60.

[12] Mgbada JU, Ohajianga DO, Nzeh EC. Sustainable practices and its determinants in South-East Nigeria. Journal of Advanced Agricultural Technologies. 2016; 3(3): 170-174.

[13] Mwalupso GE, Korotoumou M, Eshetie AM, Alavo JPE, Tiian X. Recuperating dynamism in agriculture through adoption of sustainable agricultural technology: Implication for cleaner production. J. Clean Prod. 2019; 232: 639-647.

[14] Nzeakor FC, Aigbokie SO. Adoption of Yam Storage Techniques and Food Security Status of Rural Farmers in Enugu State, Nigeria. Journal of Community \& Communication Research. 2021; 6(1): 30-37.

[15] Okringbo JI, Ominikari AG, Gbede OI. Adaptation strategies to climate variability being practiced by farmers in Bayelsa State, Nigeria. International Journal of Agricultural Research and Food Production. 2016; 1(3): 33-42.

[16] Ominikari AG. Assessing Farmers' Knowledge Creation, Sharing and Utilization for Selected Livelihood Activities in South-South, Nigeria. Ph.D. Dissertation submitted to the Department of Agricultural Extension and Rural Development, Michael Okpara University of Agriculture, Umudike, Abia State, Nigeria. 2021; 55-70.

[17] Ukanwolu GK. Effectiveness of technology transfer mechanisms of Imo State, Nigeria. Unpublished M.Sc. thesis in the Department of Rural Sociology and Extension, Michael Okpara University of Agriculture, Umudike, Abia State, Nigeria. 2014; 55-60.

[18] Uwandu CN, Thomas KA, Okoro CM. Utilization of agricultural information sources and adoption of animal and crop technologies among farming households in Imo State, Nigeria. Journal of Agricultural Extension. $2018 ; 22$ (1): 143-155. 